Published on Reviews in History (https://reviews.history.ac.uk)

\title{
INTERVIEW: Joanna Cohen talks to Jordan Landes
}

Review Number: 2212

Publish date: Thursday, 14 December, 2017

Author: Joanna Cohen

ISBN: 9780812248920

Date of Publication: 2017

Price: $£ 37.00$

Pages: 296pp.

Publisher: University of Pennsylvania Press

Publisher url: http://www.upenn.edu/pennpress/book/15632.html

Place of Publication: Philadelphia, PA

Reviewer: Jordan Landes

In the latest of our occasional Reviews in History podcast series, Jordan Landes talks to Joanna Cohen about her new book and the role and nature of the consumer in the US throughout the nineteenth century.

Joanna Cohen is a Senior Lecturer in American History at Queen Mary University of London.

Jordan Landes is History Subject Librarian at Senate House Library, University of London.

The full interview is available here [2].

\section{Other reviews:}

Times Literary Supplement

https://www.the-tls.co.uk/articles/private/social-studies-122/ [3]

Author's Corner

https://thewayofimprovement.com/2017/02/23/the-authors-corner-with-joanna-cohen/ [4]

Source URL:https://reviews.history.ac.uk/review/2212

\section{Links}

[1] https://reviews.history.ac.uk/item/295441

[2] http://podcast.ulcc.ac.uk/accounts/SAScasts/ReviewsinHistory/LandesoCohenedited.mp3

[3] https://www.the-tls.co.uk/articles/private/social-studies-122/

[4] https://thewayofimprovement.com/2017/02/23/the-authors-corner-with-joanna-cohen/ 